\title{
AN ANALYSIS OF CULTURAL CONTENT IN THE TEXTBOOK "PATHWAY TO ENGLISH” FOR SECOND GRADE IN SENIOR HIGH SCHOOL
}

\author{
Ine Nurjanah \\ IAIN Syekh Nurjati Cirebon \\ inenurjanah3@gmail.com \\ Amroh Umaemah \\ IAIN Syekh Nurjati Cirebon \\ amrohumaemahlayar@gmail.com
}

\begin{abstract}
Some teachers English only focus on students' four skills and do not introduce about the culture, especially in learning English. Then, the student don't know about the culture. Cultural content is not taught directly. It can introduce through the textbook. So this way the important thing to the teacher should choose the appropriate textbook for teaching and learning language without leaving the culture that represented in the textbook. This research investigates the representation of culture-related contents in English textbooks entitled "Pathway to English" that published by Erlangga for second grade in senior high school in Indonesia. A content analysis of these textbooks was conducted, using two aspects of culture, 'cultural categories' and the 'cultural dimensions' as the evaluation framework. In this research analayzed 14 chapters, 53 reading passages that was analyzed. Based on the result of the data that was analyszed. The are two aspect that present in this research. The first aspect is the cultural categories of Cortazzi and Jin (1999), and that has most huge amount of the porpostion is target culture. The country that use English as official language. Next, the other cultural categories that has small part is local culture and the last which has the the smallest part is international culture. The second aspect is five dimentions of Moran's theory (2001). The most that has huge amount of porpotion in five dimentions is product the second part is person and community. Practice and perspective are the small part that represent in the textbook.
\end{abstract}

Keywords: textbook, culture, cultural categories, five dimentions

\section{INTRODUCTION}

Nowdays, textbook plays a central role in teaching English in the classroom. In Hutchinson and Torress' point of view (1994) said that ELT textbooks play a pivotal role in innovation. They think that textbooks can support teachers through potentially disturbing and threatening change processes, demonstrate new and/or untried methodologies, introduce change gradually, and create scaffolding upon which teachers can build a more creative methodology of their own. Also, according to Graves (2000) said that textbook is a book used as a standard source of information for formal study of a subject and an instrument for teaching and learning.In the other side, Richard (2001) argues that textbooks are the key component of language teaching serving as the basis for much of the language input learners receive when learning a language. Then 
Karamouzian (2010) said that textbooks are seen as central to teaching and learning, as their quality is a determining factor in enhancing or diminishing the quality of a language program. Textbook is a device to help students to get not only familiar with the linguistic aspects of the language but also with social and cultural aspects embedded in language.

Language is an important thing for people as a means of communication. It cannot be studied without contents, cultures, or wisdoms of its community or nation. In addition, culture cannot be expressed and communicated without language. As any language is inseparable from its culture, teaching a new language will inevitably involve teaching a new culture. Meanwhile, English as an international language which is used as a means of communication among nation in the world either in spoken or written interaction makes the interest in learning English grow very rapidly.

Then when we use the language is closest to relate by the cultute. As Marcus said that if people without the knowledge of their past history, orgin and culture is like a tree without roots. The quote tells to human in life. Every people do not live alone, but they live with the other people and enviroment, to konw each other and interact together. People must have knowledge about their past history, orgin and culture because it is the first they grow and learn in their place by their identity. Culture is the important thing that every nation in the world. All aspects in life is based on the culture. The language that they use, the atittude that they do in life and many things in their life do by their community.

Culture is complicated to describe. Culture is the complex thing reflected in every aspect of life. As Dewantara said that culture ias the fruit of the human mind, is the result of human struggle againts two strong influence: nature and society. Then, in Hofstede (1991)'point of view that the culture to be as " the software of the mind", meaning the shared rules that guide us to behave properly in a certain group. The language is the primary tool to open the cultural heritage of another people or that knowledge of another language enables individuals to increase their personal culture through contact with great minds and attitudes. Culture refers to "the the total way of life of people composed of their learned and shared behavior patterns, value, norms, and material objects." Then, culture influences the way how the community lives, behaves, thinks, and speaks. Based on Yen (2000) said that cultures are learned by powerful human creations that afford a common identity and support meaning making in any given society. That means: culture is not inherited, but learned; it doesn't derive from a person's genes, but from one's social environment. Additionally, language and culture have intricate significance that makes the two impracticable to separate (Brown as cited in Magogwe, 2009). In other words, language and culture are indivisible.

To interact each other, someone needs a tool for getting the understanding. Language is a tool that important thing for every human to communicate each other. Brown (2000) wrote "a language is a part of a culture, and a culture is a part of a language; the two are intricately interwoven so that one cannot separate the two without losing the significance of either language or culture." In other words, language is regarded as a means by which people communicate and interact with others, which in turn is responsible for cultural development.

In light of the inseparable relationship between language and culture, more and more scholars and educators have emphasized the significant role of culture in language teaching and learning. It means that teacher must be aware of other target culture than only British and American culture in teaching-learning. 
Nowdays, most of the teachers teach the language only focus to improve students' four skill and do not explain about the culture when they teaching and learning language, especially in learning English. Then, the student don't know about the culture. One of the source that can increase the cultural awrness to the teacher and student through textbook. Richard (2001) stated that textbook is the component in every language program. It means that every language program textbook input learners receive and language practice that occurs the classroom while teaching learning are processing. Textbook can help teacher to explain what are the cultural content when they learn English. On the other hand, textbook that contains culture can influence of teaching materials on students' awareness.

However, In Inidonesia, the purpose of general education is educating Indonesian students' to be religious, well-mannered, healthy, smart, creative, independent, responsible, nationalist and democratic citizens. The purpose of education in Indonesia is set according cultural value and ideology of the nation and applied in all school and subject including English. That's way the importance of cultural content in the textbooks has rarely been addressed in prior studies, though the representation of culture-related materials has a serious impact on shaping learners' views of other cultures. Recognizing the significant influence in English textbooks on learners' cultural awareness and intercultural knowledge, this research examines how textbooks represent foreign cultures from the multicultural perspective. Using a content analysis of English textbook for the second grade senior high school in Indonesia education, the researchers investigate the representation of textbook materials from the two aspects of cultural elements: the perspectives on cultural dimensions (Moran, 2001), on cultural categories (Cortazzi \& Jin, 1999).

In this research, the 'cultural dimensions' are extended to five factors (culture as products, practices, perspective, communities, and persons) by including Moran's (2001). Additionally, the 'cultural categories', which are termed the identification of sources of cultural information, are analyzed using Cortazzi \& Jin (1999) framework of three factors: source culture (SC), target culture (TC), international culture (IC).

\section{METHOD}

In this research used a study of content analysis to reveal the cultural content in the textbook "Pathway to English" for the second grade of Senior High School. The data that were analyzed 53 of reading passages. As Fraenkel (1996) stated that the content refers to words, meanings, symbols, themes, or any messages that can be communicated, and the text is anything written, visual, or spoken that serves as a medium for communication. The instrument of the research is researcher herself. Furthermore, a retrospective analysis may test the validity of a predictive analysis and point out which steps should be taken to improve it (Skopinskaja, 2003).

The instrument of this research is the researcher herself. Because this research uses qualitative design which is content analysis. The researcher could creates the specifict setting of participant in collecting data in her research (Lodico, 2006). The documentary analysis is used to collect the data, Arikunto (2010). In analyzing the data, the writers conduct some steps. Firstly, the researcher identified and classified the data of the cultural categories into the precentage. Secondly, after classifying, the researcher investigated the frequency of each dimension of culture is then converted to percentages for comparison purpose. These percentages are then analyzed to determine which 
culture representation in the textbooks and which dimension of culture occurs the most frequently. Findings are then presented in the form of charts and pictures. The findings are then discussed qualitatively to report the research questions.

\section{FINDINGS}

In this research was analyzed the cultural content that realized in this textbook "Pathway to English" for the second grade of senior high school that published by Erlangga. There are two findings that were analyzed. The first part is the cultural categories and the second part is five dimentions. Both of them show by two pie charts.

\section{Cultural Categories}

Three categories of culture presented in textbook that were based on the idea of Cortazzi \& Jin (1999). They distinguish three categories of cultural information that can be used in language textbooks and materials. They are: Local culture, Target culture, and International culture. The cultural categories that realized in the textbook shows by chart pie below.

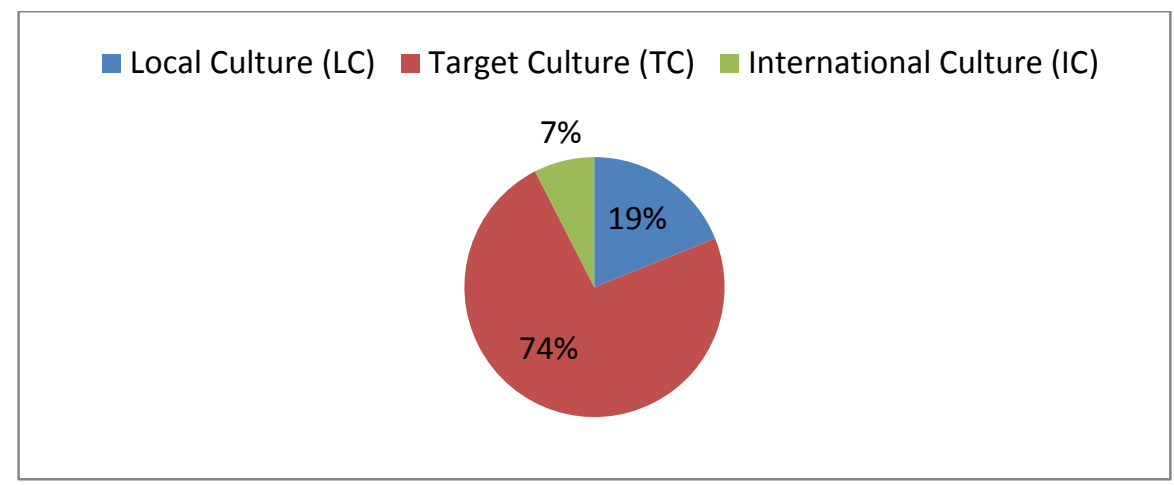

Chart Pie 1 The Cultural Categories

\section{Cultural Dimentions}

This research was analyzed five dimention of cultural content in the textbook that adopted by Moran (2001). He defined culture as the interplay of products, practices, perspectives, communities and persons. The chart pie below shows the finding that researcher has found.

\section{Pie Chart 3.1 Cultural Dimentions' Representation}

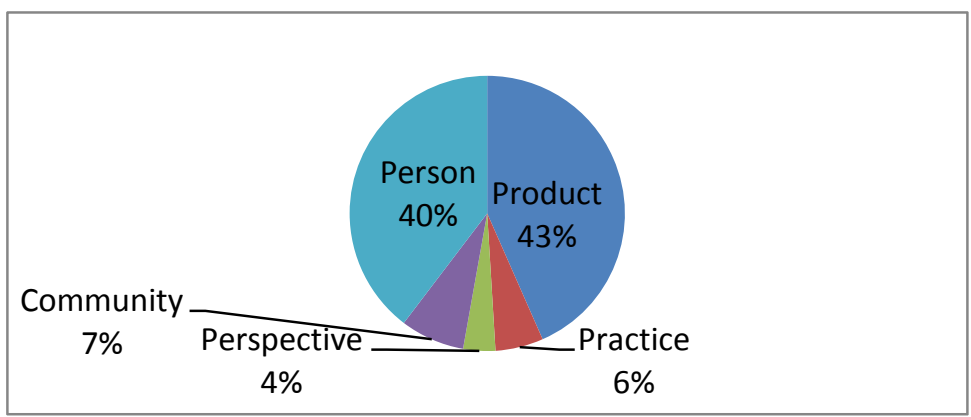




\section{DISCUSSION}

Based on the research findings above, there are two parts that were analyzed by researcher. The categories culture and five dimentions that representation in the textbook "Pathway to English" for the second grade of senior high school that published by Erlangga.

\section{Cultural Categories}

There are three cultural categories that discussed. Based on chart 2.1 above, the chart shows the proportion of three cultural categories from Cortazzi and Jin (1999). Three categories of culture presented in textbook. They distinguish three categories of cultural information that can be used in language textbooks and materials. They are: Local culture, Target culture, and International culture. In this sample data used 14 chapters from the book that entitled "Pathway to English" for second grade in senior high school that published by Erlangga. This textbook applies curriculum 2013 that used in Indonesian education. This textbook arranged by Theresia M. Sudarwati and Eudia Grace. The editor of this textbook are E. Tiyas Utami, Dwi Wahyu Priyanto, and Raymond S. The layout of this textbook sets by Erlangga with Mac OS X (Adobe Garamond Pro 12 pt).

After analyzing every chapters there are 53 texts of reading passages that found by the researcher. There are the proportions local of culture, target culture and international culture. The cultural category that has huge amount that represents in the textbook is Target Culture. Local culture has a small part and the smallest part is International culture This book has appropriated, because in this textbook most of them from the target culture or the country that used English as official language. The cultural categories that represent will increase the student knowladge about the culture. From the textbook also represent about the local culture, it means that student learn language without forgeting the own culture of the student. The local culture is located in Indonesian culture. Then the last is international culture that get the less portion, but it can increase the awarness of student to know about international culture.

The example of the cultural categories described below

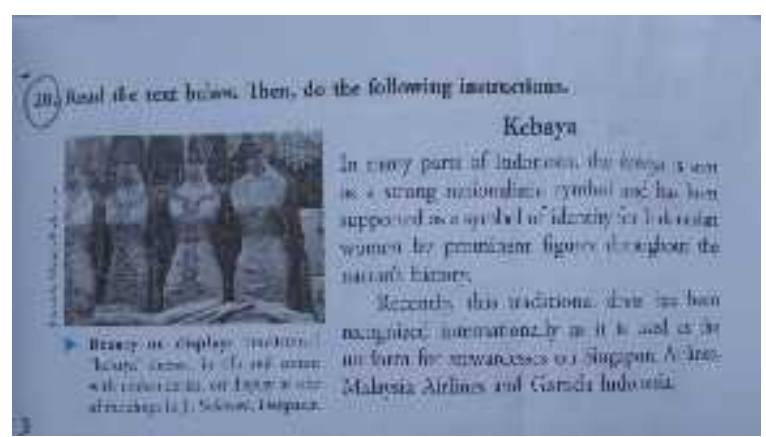

Picture 1 Traditional Cloth as the Local Culture

Based on the example above, it is one of the traditional cloth from Indonesia. kebaya has come to refer to a garment whose origins appear to be a blouse. It was first worn in Indonesia at some time during the 15th and 16th centuries. The most dominant form of kebaya worn on the islands of Java and Bali today, can be visibly traced to the 
kebaya worn in Java and Sunda from the late 19th - early 20th century onwards. Then, Kebaya is a symbol of identity for Indonesian women prominent figures throughout the nation's history.Based on the picture the students know about their own culture about one of the tradional dress from Indonesia.

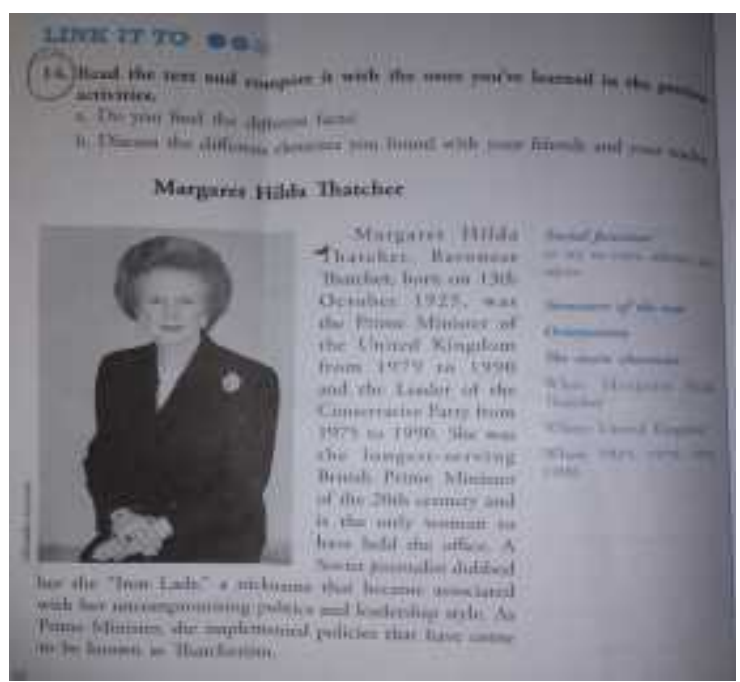

Picture 2 Margaret Hilda Thatcher

Picture 2 shows the person who get many titles. Margaret Hilda Thatcher, Baroness Thatcher, LG, OM, DStJ, PC, FRS, HonFRSC was a British stateswoman who served as Prime Minister of the United Kingdom from 1979 to 1990 and Leader of the Conservative Party from 1975 to 1990. She was the longest-serving British prime minister of the 20th century and the first woman to hold that office. From the background life of Mrs. Margaret, it includes in Target Culture.

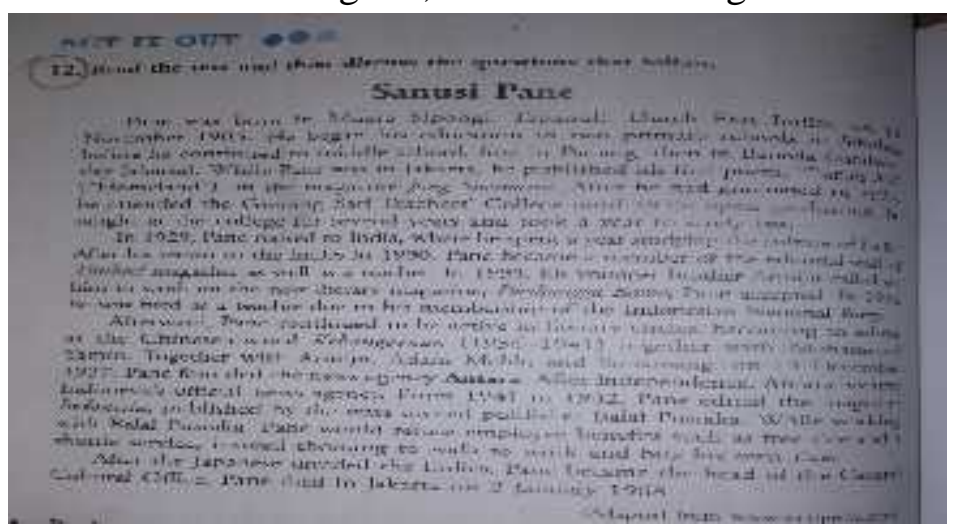

Picture 3 a paragraph about Sanusi Pane

Picture 3 shows a person from Tapanuli. Sanusi Pane (14 November $1905-2$ January 1968) was an Indonesian writer, journalist, and historian.[1] He was highly active in literary media, sitting on the editorial boards of several publications. He has also been described as the most important dramatist from before the Indonesian National Revolution. It's includes of International Culture. 


\section{Five Dimentions}

Based on the sample data from 14 chapters of the textbook entitled "Pathway to English" for second grade in senior high school that published by Erlangga there are 53 texts of reading passages.

The chart shows the proportion of five dimentions of cultural content from Moran (2001) perspective. There are the proportions of product, practice, perspective, community, and person. Based on the chart, the five dimentions that most dominant is product. Most of cultural content that represent in the textbook "Pathway to English" for the second grade that published by Erlangga is product from some countries: local culture, target culture and international culture. The product includes of cloth, food, literature such as: novel, short stories, poetry and song's lyric. Then the next dimention that the second most dominant is person. Many of figures that represent in the textbook that can increas cultural awarness through life famous story person from some countries. The third is community, most of them form into groups or communities that made seminars to have a goal that gather with their communities. Next, the forth position is practice. Practice is every person act on their activity or celebrate based on their culture. Then the last is pespective. The position perspective is less than others. There are some perspective of someone in this textbook that give their perception about the condition about their country. There are some illustration that described of five dimentions below.

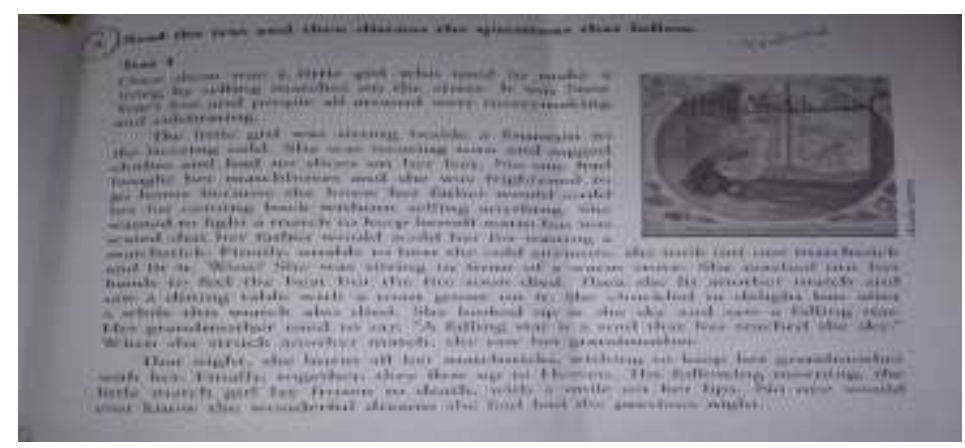

Picture 4 Short Story as Product Culture

The picture 4 is short story that named "The Little Match Girl" that written by Hans Christian Andersen. He is a Danish author. The story, about a dying child's dreams and hope, was first published in 1845. It has been adapted to various media, including an animated short film, a television musical, and an animated virtual reality story called "Allumette". text there are several turn-taking that siad by Mr. Vicar and Bill. 


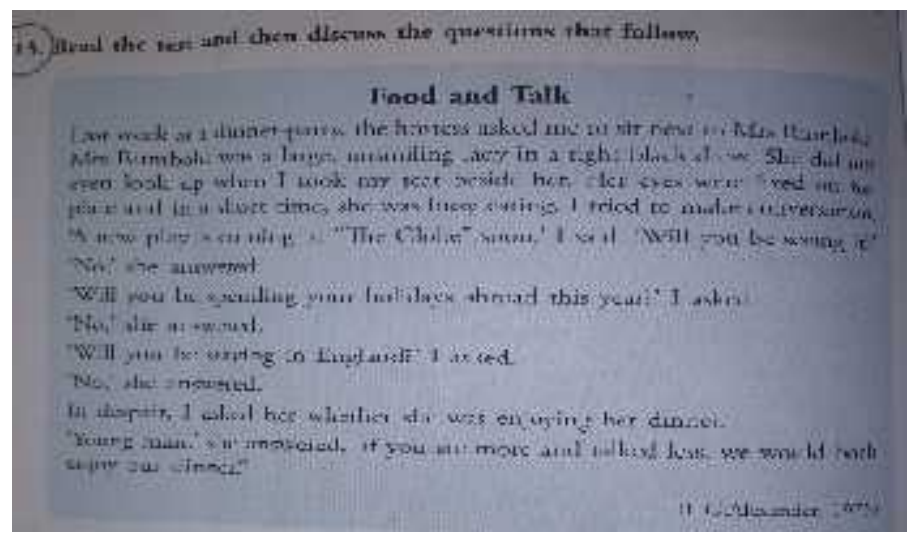

Picture 5 Food and Talks as Practice Culture

The picture 5 is in chapter 9 . The picture shows that there is practice culture in an event Food and Talk. An event was held on last week a dinner party. Then in the text there are several turn taking between a man and a woman.

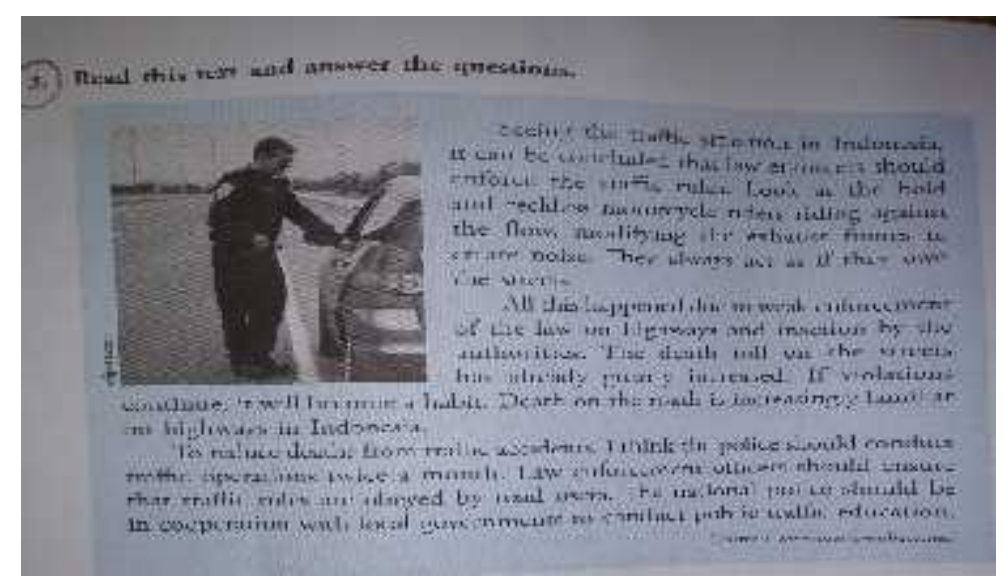

Picture 6 The Condition of Indonesia as Perspective Culture

The picture above is a perspective of someone about the situation of Indonesia. The perception about traffic in Indonesia. So he thought that the police have to conduct traffict operations twice a month. Then the national police must be in cooperatio that local goverments to conduct public traffic education.

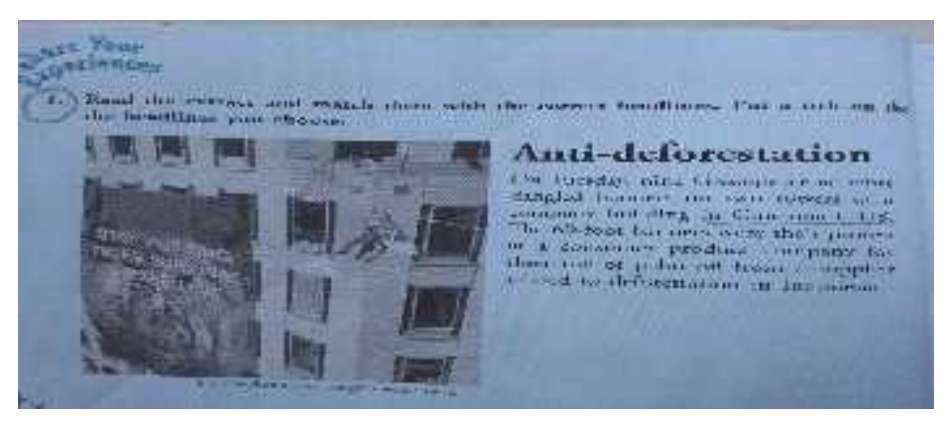

Picture 7 Greenpeace activist as Community Culture 
The picture above tells about a community of nine Greenpeace activist dangled banners on two towers of company building in Cincinati, US. They complain at a consumer product company for their use of palm oil from a supplier related to deforestation in Indonesia.

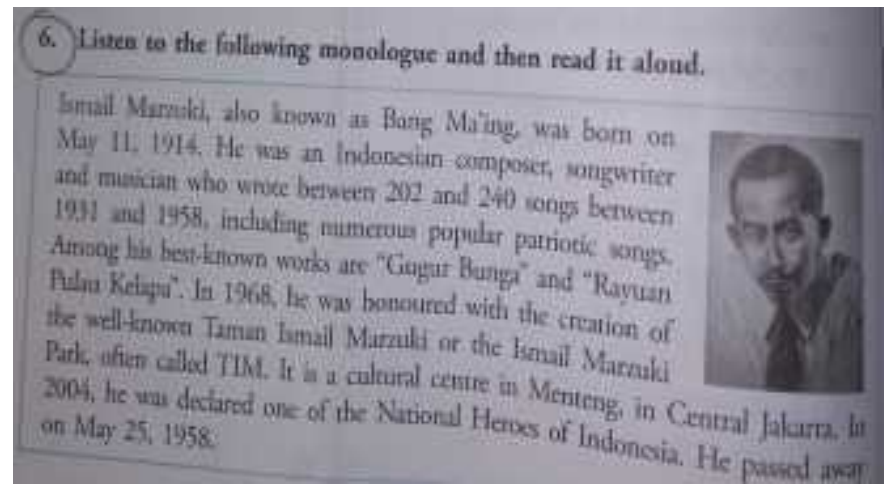

Picture 8 The National Hero as Person Culture

The picture above is the person culture feom Indonesia, Ismail Marzuki. Ismail Marzuki was an Indonesian composer, songwriter and musician who wrote around 202 to 240 songs between 1931 and 1958, including numerous popular patriotic songs. Among his best-known works are "Halo, Halo Bandung", "Gugur Bunga", and "Rayuan Pulau Kelapa". In 1968, he was honoured with the creation of the well-known Taman Ismail Marzuki (the Ismail Marzuki Park, often called TIM) which is a cultural centre in Menteng in central Jakarta. In 2004 he was declared one of the National Heroes of Indonesia.

\section{CONCLUSION}

Based on the result of the research, there are two points which can be concluded, they are:

The categories of cultural content that represent in the textbook "Pathway to English" published by Erlangga for the second grade in senior high school divided into three categories (Local Culture, Target Culture and International Culture). The researcher was analyzed that the total number of three categories of cultural content in the textbook is the most dominat to Target Culture (TC), then the second is Local Culture (LC), and the last is International Culture (IC). Student have to know about the target culture and international culture without forgeting their own culture, Indonesian Culture. Based on the data that anayzed by researcher, this textbook can used for source to the student for getting the increase of the cultural awarness, especially in target culture. Then the teacher can use this textbook as source when she/he teaches English language.

The representation of cultural content in the textbook "Pathway to English" published by Erlangga for the second grade in senior high school divided into five dimentions (Product, Practice, Perspective, Community, and Person). Then, from the result of data that was analyzed, it was descibed that Product is the most dominant in five dimentions. The second is Person. The third is Community. The forth is Practice. 
Then, the last is Perspective. From the five dimentions the product has big contribution of the cutural content that represent in the textbook. From the textbook student will know about the culture from their country and cross culture such as the colth, food and literature. Then, it is not only product, the person gives the good contribution to students' cultural awareness through their life story.

\section{REFERENCES}

Arikunto, S. (2010).Prosedur Penelitian Suatu Pendekatan Praktik. Jakarta: Rineka Cipta.

Brown, H. D. (2001) Principles of Language Learning and Teaching. Beijing: Foreign Language Teaching and Research Press.

Cortazzi, M. \& Jin, L. (1999). Cultural Mirrors: Materials and Methods in the EFL Classroom, in Hinkel, E. (ed.), Culture in Second Languag Teaching and Learning. Cambridge: Cambridge University Press.

Dewantara, K.H. (1994). Bagian II Kebudayaan. Yogyakarta: Majelis Luhur Taman Siswa.

Fraenkel, J. (1996). How to design and evaluate research in education (3rd ed.). New York: McGraw-Hill, Inc.

Grace, Eudia \& Sudarwati M. Theresia.(2015).Pathway to English. PT. Gelora Aksara Pratama: Penerbit Erlangga.

Graves, K. (2000). Designing Language Course, A Guide for Teachers. Boston.

Hofstede.(1991).Cultures and Organizations, Software of The Mind. England: McGraw-hill Book Company.

Hutichinson and Torres.(1994). The Textbook as Agent of Change. ELT Journal. https://academic.oup.com/eltj/article abstract/48/4/315/2724140. Cited on August 2018

Karamouzian, F.M. (2010). A Post-Use Evaluation of Current Reading ComprehensionTextbooks Used in TEFL Programs.The Iranian EFL. Journal,Vol. 6 (4).

Lodico, G, Marguerite, Dean T. Spaulding, Katherine H.Voegtle. (2006).

Methodsin Educational Research From Theory to Practice San Fransisco. Jossey Bass.

Moran, Patrick R. (2001). Teaching culture: Perspectives in practice. Boston, MA: Heinle \& Heinle.

Richards, J.C. (2001). Curriculum Development in Language Teaching. New York: Cambridge University Press.

Skopinskaja, L. (2003). The role of culture in foreign language teaching materials: an evaluation from an intercultural perspective (Incorporating intercultural communicative competence in language teacher education ). European Centre for Modern Languages, Council of Europe Publishing.

Yen, Y. (2000). Identity Issues in EFL and ESL Textbooks: A Sociocultural Perspective. PhD. thesis. The Ohio State University, USA. Retrieved September 11, 2018 from http://etd.ohiolink.edu/view.cgi?acc_num=osu124284567 